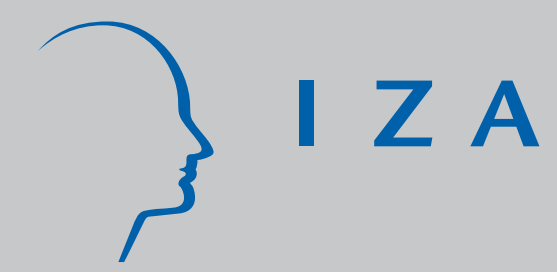

IZA DP No. 3941

Are Public Sector Workers Underpaid in Russia?

Estimating the Public-Private Wage Gap

Vladimir Gimpelson

Anna Lukiyanova

J anuary 2009 


\title{
Are Public Sector Workers Underpaid in Russia? Estimating the Public-Private Wage Gap
}

\author{
Vladimir Gimpelson \\ CLMS, Higher School of Economics \\ and IZA \\ Anna Lukiyanova \\ CLMS, Higher School of Economics
}

Discussion Paper No. 3941

January 2009

IZA

P.O. Box 7240

53072 Bonn

Germany

Phone: +49-228-3894-0

Fax: +49-228-3894-180

E-mail: iza@iza.org

Any opinions expressed here are those of the author(s) and not those of IZA. Research published in this series may include views on policy, but the institute itself takes no institutional policy positions.

The Institute for the Study of Labor (IZA) in Bonn is a local and virtual international research center and a place of communication between science, politics and business. IZA is an independent nonprofit organization supported by Deutsche Post World Net. The center is associated with the University of Bonn and offers a stimulating research environment through its international network, workshops and conferences, data service, project support, research visits and doctoral program. IZA engages in (i) original and internationally competitive research in all fields of labor economics, (ii) development of policy concepts, and (iii) dissemination of research results and concepts to the interested public.

IZA Discussion Papers often represent preliminary work and are circulated to encourage discussion. Citation of such a paper should account for its provisional character. A revised version may be available directly from the author. 
IZA Discussion Paper No. 3941

January 2009

\section{ABSTRACT \\ Are Public Sector Workers Underpaid in Russia? Estimating the Public-Private Wage Gap ${ }^{*}$}

The paper starts with discussing institutional framework for public sector wage setting in Russia. Given that individual choice of the sector is endogenous to wages, the authors recommend alternative econometric techniques for the public-private wage gap estimation. Applying switching regression that allows correcting for non-random sector selection, the paper provides wage gap estimates for various demographic, occupational, and territorial population subgroups. As it is shown, there is significant cross-group variation in the wage gap. The paper concludes that to eliminate the negative gap wages in the public sector should be linked to the private sector wages at the regional level.

JEL Classification: J31, J45

Keywords: public sector

Corresponding author:

Vladimir Gimpelson

Centre for Labour Market Studies

Higher School of Economics

20 Myasnitskaya St

101990 Moscow

Russia

E-mail: vladim@hse.ru

* The authors are grateful for helpful comments from R. Kapeliushnikov and M. Lokshin. 


\section{Introduction}

The topic of underpaid public sector employees has recently loomed large in discussions on economic and social policy in Russia. Over the past 15 years, average wages in education and public health, which form the bulk of the public sector, varied between $40 \%$ and $60 \%$ of the average wage in industry. Even by the end of 2007, after repeated revisions of the mandatory minimum wage, it did not exceed the upper limit of this band.

A simple comparison of average wages across sectors and industries does not provide sufficient grounds for deriving a conclusion that there are wage gaps between the sectors. Nor does it indicate the size of the gap because workers in different sectors have different levels of education, skills and experience. Besides, high wages may compensate for hazardous labor conditions, climate disamenities and other negative aspects of work. Finally, in choosing their occupations people are guided not only by earnings perspectives but also by personal predispositions and preferences. All this implies that dealing only with average wages aggregated for all the surveyed workers across several sectors one ends up with comparing incomparable entities. Such assessments should be treated as approximations at best. However, if one tries to take into account all the above differences what would then be the wage differential between the public and private sectors? Is it the same for all groups of workers? How different is the gap in regions with different levels of economic development? Finally, if the gap between average wages is so large, what is the reason?

Note that problems at the labor market may arise both if public sector employees are underpaid and if they are overpaid. Negative wage differentials give rise to adverse selection and drag down wages in entire economy thereby inflating ineffective employment and encouraging corruption. Conversely, wage advantages of the public sector relative to the private sector tend to crowd out private employment and reduce overall employment, as shown by the evidence from Western Europe. ${ }^{3}$

There is ample economic literature discussing public-private wage gaps in many developed and developing countries. Most of the studies reveal that public sector workers are likely to get a positive wage premium relative to private sector workers if major individual and job related characteristics are controlled for. This empirical conclusion corresponds well with the institutional framework within which the public sector pays wage rates prevailing in the private sector. Higher job security and unionization of public sector workers (teachers, doctors, municipal and postal workers, etc) as well as a political clout around many public sector activities strengthen their bargaining power easing access to rent (wage premia).

3 Algann Y., P.Cahuc, and A.Zylberberg (2002) Public Employment and Labour Market Performance, Economic Policy, Vol.17, 34, 7-66. 
Russia, so far, has been exempt from the list of countries where the public-private wage gap is exposed to scrutiny. Two particular reasons make the Russian case quite interesting. First, the wage setting framework here seems to be rather different and its wage outcome can be less obvious. Second, the large public sector in Russia can put strong pressure on private sector wages.

As a point of departure, we consider the public sector as consisting of organizations in public health, education, culture and public administration, which are mostly state owned and produce public goods being funded from the federal and regional (local) budgets. ${ }^{4}$ According to official quotes, 14.4 millions employees, or about $22 \%$ of total employment, receive their wages from the budgets of various levels. In 2003, 88.8\% of all employed in public health worked in state-owned establishments; in education and culture this proportion was $96.0 \%$ and $84.3 \%$, correspondingly.

In the beginning of economic transition in 1992, real wages in the public sector dropped more dramatically than in the rest of economy (Figure 1). The same pattern of drastic fall was repeatedly observed after the 1994 and 1998 macro-shocks. Only public administration made an exception with a relatively small shock-induced drop in wages followed by rapid after-shock wage recovery. By 1999, the real wage in the three major sub-sectors of the public sector made just one third of the 1991 level. However, the wage growth in the public sector has accelerated since that and by 2004 it has increased threefold compared to the 1999 level. Nevertheless, the inter-sectoral difference in the wage growth rates was not sufficient to compensate for the wage gaps that emerged earlier.

Figure 2 shows the evolution of the mean wage in the public sector relative to the mean wage in industry. The gap between them has been large and robust over the whole period starting from 1992. The wage of an average public sector worker has fluctuated at the level of around 50$65 \%$ of the wage of an average industrial worker, though the former is much better educated than the latter. Therefore, the presence of significant public-private wage gap appears to be undisputable fact even from the raw data, i.e. when important skill differences between the sectors are ignored. Accounting for these structural differences and thus measuring gaps for comparable workers is likely to widen the gaps.

The rest of the paper is structured as follows. In the next section we outline the institutional framework for the public sector wage setting. The data description and main definitions are presented in Section 3. In Section 4, we show the descriptive picture for publicprivate wage gaps using unadjusted wage estimates. Then we move to the regression analysis, which is discussed in Section 5. Here, we present econometric methodology and estimates from

\footnotetext{
${ }^{4}$ This definition is not used throughout the paper. We slightly modify it in subsequent sections to fit our microdata.
} 
OLS and switching regressions. Section 6 deals with intersectional transitions and uses fixedeffect model. Public-private gaps in cross-regional perspective are investigated in Section 7 and Section 9 concludes.

\section{Wage-Setting in Russian Public Sector: Institutional Framework}

Organizations in the public sector are not profit maximizers and are directly administered by the government that may strongly politicize decisions in relation to this sector. ${ }^{5}$ On the contrary, private sector wages are supposed to be set by the competitive market. Therefore, wage-related market signals have to be translated from the private sector labor market into the public sector. The capabilities of the government to receive these signals and transform them into public sector wages (without bending to political interests) affect the very existence and magnitude of the public-private wage gap.

The market-driven wage setting leaves little room for bureaucrats to manipulate wages. In this sense, public sector wages have become exogenous for the state as an employer and are fixed by the private sector directly or through negotiations with the unions. What is left here for bureaucrats is to regulate the quantity of employment within given budget constraints.

In Russia (as well as in other CIS countries), wage-setting framework in the public sector is completely different from that in the OECD countries. It does not account ex ante for relative wages as they emerge at the competitive labor market. Wages usually consist of two parts guaranteed or basic and variable. Basic (i.e. tariff-based) component of the budgetary sector wage is defined by the federal authorities through politico-bureaucratic bargaining over the statutory minimum wage (MW) and the Unified Tariff Scale (UTS) ${ }^{6}$, while the further adjustment emerges spontaneously through the variable part as a response to market forces.

The basic (tariff) wage in the budgetary sector is the UTS-based. The minimum UTS grade is linked to the MW, level of which is fixed uniformly by the federal legislation and does not vary across the regions. The UTS and MW upward adjustments emerge irregularly as a byproduct of politico-economic bargaining and expected budget revenues. Therefore, they are linked to world commodity (that make up the major share of Russian exports and thus are

${ }^{5}$ For international surveys and theory see: R.Ehrenberg and J.Schwarz. Public Sector Labor Markets. Handbook of Labor Economics, Chapter 22, Vol.II, Ed.by O.Ashenfelter and R.Layard, Elsevier, 1986; R.Gregory and J.Borland, Recent Developments in Public Sector Labor Markets. Handbook of Labor Economics, Chapter 53, Vol.III, Elsevier, 1999.

${ }^{6}$ The Federal Law No.122 (2004) allows regional governments not to stick to the UTS grades in wage determination in the budgetary organizations which are in regional/municipal jurisdiction. However, we have no evidence that this legislative amendment is actively used. 
responsible for budgetary revenues) prices and domestic politics but completely disregard regional labor markets equilibria. Meanwhile, the UTS determines not the actual consumer wage level itself but its lower bound guaranteed by the state. How far upwards the wage can actually move depends upon other factors. ${ }^{7}$

Since the UTS and MW levels are not regionally sensitive, fixing their levels the central government has to account somehow for regional heterogeneity and is therefore constrained by fiscal position of the weakest region. This makes basic wage for public sector workers in all other (better-off) regions understated comparing to competitive wages at the relevant regional labor markets. The more developed a region is, the better its fiscal position and the higher current private sector wage is, the stronger its upward pressure on budgetary sector wages can be. All this generates pressure on the public sector and drives its wages up with using additional over-tariff bonuses or premium. The premium size reflects not only regional/local fiscal resources, but the bargaining power of education/health care administrators and trade unions as well. This logic predicts that public sector workers in economically advanced regions are likely to have higher actual nominal wages than in depressed regions. However, at the same time the public-private wage gap will be larger in advanced regions since the gap between the UTS-based pay and the private sector wage widens and accommodating for it becomes more difficult. Fig. 3 illustrates the wage setting mechanism described above.

In fact, regional bureaucrats "share” budgetary revenues with teachers or doctors when regional fiscal position is good and workers' voice is loud enough. On the contrary, they keep wages close to the UTS-based lower bound when revenues are scarce and the voice is weak. Procyclical regional fiscal policies contribute to inter-regional differentiation and impose additional risks on regional budgets. ${ }^{8}$

The mechanism of wage setting based on the revenue sharing appears to be a systemic feature of the Russian economy. In Russian corporations, managers who enjoy significant power over workers (like bureaucrats in the public sector) also tend to tie workers' wage to firm economic/financial performance instead of relating it to individual productivity. In fact, they share revenues with workers in "good times" and losses in "bad times". 9 This makes the wage setting machineries in the public sector and in the old industrial sector quite similar, and both fit

${ }^{7}$ Tariff-based pay makes less than 50\% of the total wage bill in education and $34-38 \%$ in public health organizations, which are under regional or municipal jurisdiction.

${ }^{8}$ Kwon G. and A.Spilembergo (2004) “Russia’s Regions: Income Volatility, Labor Mobility and Fiscal Policy”. In: Russian Federation: Selected Issues. IMF Country Report 04/316, IMF, Washington, September 2004.

${ }^{9}$ Kapelyushnikov R. (2003) “Wage-Setting Mechanisms in the Russian Industry”, HSE Working Paper No.WP3/2003/07. 
well the model which we call (after Richard Layard) "the Russian model in labour market adjustment”. ${ }^{10}$

Therefore, the centralized approach toward wage setting of public sector workers based upon minimum wage standard that is uniform for the whole country is likely to drive down wages in the sector. This turns potential public sector premium into actual penalty.

Underpayment of public sector workers relative to private sector workers with comparable characteristics may is likely to induce negative selection into the public sector. Then, the public sector being a large employer sends feedback signals to the commercial sector stimulating wage containment. This drives all wages down in exchange for excessive employment. This effect is especially visible in depressed regions where bloated public employment is combined with underdeveloped private sector.

This short institutional overview brings us to formulating a few hypotheses related to the public-private wage gap. First of all, we expect that for most of public sector workers this gap (adjusted for personal characteristics) to be associated with a penalty not a premium. Secondly, the gap is likely to vary across social and demographic groups depending on the bargaining power of a particular group. Thirdly, the gap is expected to be smaller in more depressed regions. In the next sections, we are dealing with testing these hypotheses.

\section{Data and Definitions}

In estimating wage gaps we rely on two sets of microdata. First of all, we use the RLMS data set for 2000-2004. The RLMS is a representative household panel study that allows capturing cross-sectional as well as temporal variation. We limit our study to this time period due to three main reasons. First, this was a period of stable economic growth with no negative shocks for the labor market. Such macroshocks could bring short-term but significant deviations of the relative wage from its long-run equilibrium level. Second, during this period the MW was raised several times shifting up the whole UTS. The third reason was that the surveys were conducted annually during this period (not bi-annually as in the earlier period).

As an additional source for estimating the wage gap and its geography we use the NOBUS data. ${ }^{11}$ The NOBUS was conducted by the Russian Statistical Agency (ROSSTAT) and the World Bank in Q2 2003. It is a cross-sectional survey but has a large sample of around 45000 households covering all Russian regions and is representative for 46 of them.

\footnotetext{
${ }^{10}$ The main property of this model is in an extraordinary wage flexibility paired with stability of employment.

${ }^{11}$ NOBUS is the transliterated Russian abbreviation for the National Survey of Household Wellbeing and Participation in Social Programs.
} 
Our sample is restricted to individuals aged 15-72 and excludes self-employed. We identify our respondent as a "public sector worker" if he/she is employed in education, health care, or public administration and marks the government ownership for his employer. Public sector workers made $25.3 \%$ of total employment in the RLMS sample for 2000-2003. In NOBUS, the relevant proportion is slightly higher and equal to $27 \%$. All other employees are considered as being employed in the private sector. ${ }^{12}$

The dependent variable is the logarithm of monthly wage. To compare wages over time and account for region-specific inflation rates we deflate the nominal wage by monthly regional CPIs. In our regressions, in order to account for all job-related income we control for major nonpecuniary benefits linked to jobs, and for earnings from secondary employment. We also control all major individual characteristics (gender, age, tenure, education, family status, occupation) and job-related characteristics (town/city size, firm size, working hours and employment conditions). The RLMS offers also subjective measures such as life and job satisfaction, fear of job loss, willingness to change job, and self-estimate of difficulties associated with job mobility.

\section{Descriptive Analysis of the Public-Private Wage Gap}

\section{Employment composition}

According to Table 1 the employment composition differs in the both sectors. First, in the public sector, women are more likely to have tertiary education and to belong to the group of professionals. Workers occupations, on the contrary, concentrate outside the public sector. Second, relatively more public sector workers reside in small towns and rural area. Third, public sector workers have on average 8.5 years of tenure compared to 7.4 years for private sector workers. Longer tenure suggests lower inter- and intra-sectoral mobility. Fourth, workers in the both sectors differ only slightly in terms of age but the proportion of pensioners is significantly higher among public sector workers (17\% vs $10-11 \%)$. This can be explained by the fact that women in Russia retire at 55, 5 years earlier than men, and the public sector is womendominated. Fifth, the duration of working week in the public sector is shorter by 5 hours.

The above-mentioned compositional differences are likely to have different impact on the wage gap. Higher education and longer tenure, other things being equal, tend to increase relative wage. Meanwhile, shorter working hours and disproportionately large shares of women and rural residents may have the opposite effect.

12 These estimates are close to official estimates from the Russian Labour Force Survey measuring employment in education, public health and public administration as $25 \%$ of the total. 
What is the Wage Gap: Preliminary Estimates

Tables $2 \mathrm{a}$ and $2 \mathrm{~b}$ summarize the estimates for the public-private sector wage gap from the RLMS and NOBUS data, respectively. Column 2 in the both tables presents unadjusted sectoral wage differentials measured in percent of the relevant private sector wage ${ }^{13}$. In all population sub-groups public sector workers receive less than the opportunity wage. Though the RLMS-based estimates are two times higher than the NOBUS-based estimates the signs and the structure of the wage gap are similar in the both data sets. In the further discussion, we mostly rely on the estimates from the RLMS, while NOBUS-based estimates are used for cross-regional comparisons only.

The RLMS data suggests that wages in the public sector are on average $40 \%$ lower than in the private sector. In 2002, the wage gap contracted to $-34 \%$ but later on it returned to the initial level. For the whole period under consideration, the magnitude of the sectoral wage differential hardly changed in spite regular increases in the minimum wage, which is the nominal anchor for public sector wages. Gender-specific wage gaps are significantly smaller than the gap for the whole sample. This difference can be explained by gender asymmetry in the occupational structure. Since women are disproportionally concentrated in the public sector, the gender wage gap reinforces the sectoral wage gap.

Differences in earnings can vary depending on the level of experience, education and skill of a worker, and on the demand and supply conditions for various types of labor. The sectoral gap tends to diminish with workers' age reflecting the fact that wage ladders in the public sector are to a greater extent dependent on seniority and tenure. Larger negative differential is observed among the workers with lower education and skills as compared to highskilled workers. The public-private wage differentials are higher in urban as compared to rural areas. Premiums for employment in the private sector increase with the size of the settlement. More competitive environment in larger cities raises wages outside the public sector.

\section{Fringe benefits and working conditions}

Comparison of non-wage aspects of total compensation reveals substantial advantages to public sector employees.

First, jobs in the private sector are more often associated with intensive manual work. Only $11-13 \%$ of public sector workers are involved in this type of work compared to $33-34 \%$ of

${ }^{13}$ In order to eliminate time effects in the RLMS data we employed the following procedure. First, we estimated separate wage equations for each sector with year dummies as control variables and then calculated the wages net of year effects. The calculation of unadjusted wage differentials is based on these wages corrected for year effects. 
private sector workers (Table 1). For those working manually, its intensity is also much higher in the private sector.

Second, though the Labor Code provisions concerning social guarantees are not differentiated across sectors, their enforcement in the public sector is much more complete. Nearly all public sector workers report getting vacation payments, sickness payments and maternity leave allowances, while in the private sector these provisions are far from being universal. Higher fraction of public sector workers has access to free or subsidized health care, training and vouchers for vacation trips. In some cases private sector workers find themselves in more favorable conditions. First of all, this applies to loan access. Private sector workers are also more likely to receive subsidized meals. However, the ultimate balance is in favor of the public sector.

\section{Subjective Measures}

Overall comparative advantage of the public sector can find a reflection in subjective measures of life and job satisfaction, and of the willingness to change current job (Table 4). It is commonly accepted that preferences towards the public sector are often motivated by risk aversion behaviour at the labour market. Therefore, occupational choice is likely to be correlated with unemployment fears and uncertainty about one's chances to find a new job ${ }^{14}$. In fact, the distribution of answers to the RLMS question: "How much do you worry about possible job loss?” is skewed towards high levels of anxiety in the public sector. However, the sectoral differences are not dramatic. For instance, the risk of losing the job is perceived as high by $49 \%$ of public sector workers compared to $55 \%$ of private sector workers. At the same time, $40 \%$ of public sector workers and 34\% of private sector workers do not worry about possible job loss. Public sector workers are also more confident in their chances to find a new job at comparable contract terms. May be the true reason for that is that their reservation wage is low and low paid jobs are easily available.

Willingness to change a job is an indirect measure of satisfaction with current job. The fraction of those who want to change job is as high as two third in both sectors and differences between the two sectors are negligible.

In 2002 and 2003, RLMS respondents were asked to answer direct questions about job satisfaction. As shown in Table 4, greater fraction of public sector workers is satisfied with job

\footnotetext{
${ }^{14}$ The unemployment fears themselves may be a significant factor of wage growth moderation. For details see: Gimpelson V., Kapelyushnikov R. and T.Ratnikova (2003) "Has Fear Big Eyes? Fear of Unemployment and Wage Flexibility”, HSE Economic Journal, 2003, Vol.7, No.3 (in Russian).
} 
in general, with working conditions and career prospects while private sector workers are more often happy with their wages.

Summing up cross-sectoral comparison of non-wage aspects of work and subjective assessments, we may conclude that most but not all of non-wage and subjective features point at the clear advantages of the public sector. This proves intuitive conclusion that each sector has its own comparative advantages in terms of compensation, which cannot be reduced to wage averages. Comparing wages we should account for all possible dimensions of working conditions and work compensation.

In the next section we turn to multivariable analysis of the public-private wage gap.

\section{Regression Analysis of the Public-Private Wage Gap (Pooled OLS)}

We start with estimation of the standard Mincerian earnings equation using OLS techniques:

$$
\operatorname{Ln}\left(\text { Wage }_{i}\right)=\beta_{0}+\sum_{j} \beta_{j} x_{j i}+s D_{i}+u_{i},
$$

where $X$ 's are individual characteristics, $u$ is the error term $\left(u_{i} \sim N I D\left(0, \sigma^{2}\right)\right), D_{i}$ is equal 1 for the budget sector workers and 0 otherwise. Pooled OLS regressions implicitly impose the restriction that the returns to observed characteristics are the same for the two sectors and that publicprivate differences depend on a shift factor (dummy variable) only. Coefficient $s$ shows the magnitude of the public-private wage gap ${ }^{15}$. Equation (1) was estimated separately for each population sub-group.

We estimate the basic and an augmented specification of equation (1). Our basic specification controls only for major individual characteristics (gender, age, age squared, tenure, tenure squared, education, occupation, marital status, duration of working week, region, type of settlement) and year effects. It does not account for other aspects of employment that may have compensatory impact. In fact, such job and personal characteristics as provision of fringe benefits, opportunities for moonlighting and risk aversion may affect the selection of the sector of employment. That is why we add additional variables to equation (1) and estimate augmented specifications.

The estimation results for the RLMS and the NOBUS data are presented in Tables 2a and $2 b$, respectively. $R^{2}$ for all equations are between 0.36 and 0.60 . We find negative and statistically significant coefficients for the whole sample and for most population subgroups.

${ }^{15}$ Since wages enter the left-hand side of equation (1) in logs, the effect of having a job in the public sector is measured as $\left(e^{s}-1\right) * 100 \%$. For details see: Halvorsen, R., and R.Palmquist (1980) “The Interpretation of Dummy Variables in Semilogarithmic Equations”, American Economic Review, Vol. 70 (3), pp.474-475. 
Compared to raw wage differentials, adjusting for the difference in human capital characteristics between the sectors results in narrowing the gap. In general, conditioning on a larger set of variables further reduces the estimated differential.

Since the OLS regression ignores the endogeneity of sectoral choice, all the estimated returns are risk to be seriously biased. To address the endogeneity problem we use two alternative approaches and they are switching regression and fixed effects model.

\section{Switching Regression}

The use of switching regression is motivated by the fact that wage-setting mechanisms may differ between sectors and the choice of sector is a result of non-random selection process. To choose between the sectors, an individual compares expected net benefits in each sector and selects the job that best rewards her/his individual set of characteristics. Once an individual decides on the preferred sector, she/he enters the pool of applicants from which employers select. The probability of being selected within a particular sector depends on the individual's characteristics (observed and unobserved) as well as on characteristics of the employer. The observed individual outcome is a combination of preferences and job rationing.

The SR model contains two wage equations (one for each sector) and selection equation $^{16}$. Additionally, it assumes joint dependence of the error terms in wage and selection equations. In terms of empirical strategy, this leads to a two-stage Heckman-type estimation. On the first stage, we estimate the sector choice model and generate the selection term (similar to inverse Mill's ratio) for every alternative. On the second stage, we estimate wage equations with relevant selection terms and other explanatory variables. To solve the identification problem we include into selection equation variables that influence the choice of the sector but not the individual wage. We use a single variable (the presence of children under 7 in a household) for the RLMS data and three variables (the presence of children under 7 in a household, the presence of children aged 8-15 in a household and the dummy for part-time employment) for the NOBUS data. Having small children can motivate preferences for secure job, flexibility of working time and non-pecuniary benefits.

Having obtained unbiased estimates of returns to human capital characteristics, we can predict expected wages for each sector and derive corresponding wage differentials. We calculate the conditional wage differentials based on conditional wages in each sector. The

\footnotetext{
${ }^{16}$ For technical details see Maddala, G.S., 1984, "Disequilibrium, Self-Selection and Switching Models”, in Handbook of Econometrics, Vol.3, eds. Z. Griliches and M.D. Intrilligator, North Holland, Amsterdam.
} 
conditional wage is what the wage of public sector workers would be if they faced the wage structure prevailing in the private sector. It is presented in the equation $(2)^{17}$ :

$$
\text { Wage }_{g i}^{\text {Cond }}=\operatorname{Ex}\left\{\operatorname{Exp}\left(\operatorname{Ln}\left(\text { Wage }_{g i}\right) \mid D_{i}=0\right)\right\}=\operatorname{Exp}\left(\beta_{p} X_{g i}+\sigma_{p} \lambda_{p}+\frac{\sigma_{p}^{2}}{2}\right)
$$

where $\lambda$ is the selection term, $\sigma_{p}$ is the variance of the error term in the wage equation for the private sector, subscript $g$ denotes the public sector, subscript $p$ denotes the private sector. The magnitude of the overall gap was computed as the difference between actual and conditional average wage of public sector workers measured in percent of the conditional average. To obtain group-specific gaps the averages are taken within the relevant group.

Table 5 presents estimation results for the basic specification using the RLMS data. The Wald test confirms the hypothesis of non-random selection into the public sector. Differences in returns between the sectors show that the public sector gives higher value to education and qualifications. Public sector workers also get advantage from employment at large-size establishments. On the contrary, wages in the private sector are more sensitive to local labour market conditions as it is shown by the coefficients for the settlement type dummies.

Compared to the OLS estimates, the correction for sectoral choice narrows the overall gap from $-26-28 \%$ to $-16-18 \%$ in the RLMS data and has no effect in the NOBUS data (Tables $2 \mathrm{a}$ and $2 \mathrm{~b}$ ). The gap is approximately the same for both men and women.

The public-private sector gap varies significantly across population sub-groups. It is significantly higher for younger workers and tends to narrow with age reflecting growing returns to tenure in the public sector. Workers with completed secondary education are most severely underpaid (-26\%). Workers with tertiary education experience quite moderate though still significantly negative gaps. Among occupational groups, potential wages are the highest for skilled and unskilled blue-collar occupations (-29-33\%). Workers in other occupations could get about $20 \%$ premium if they change the sector.

Conditioning for selection into the public sector strongly affects the wage differential in economically backward regions - South, Far East, and Siberia. For these regions, the size of the gap contracts by 11-18 percentage points. For Central, North-Western and Volga regions the reduction is modest and makes about 5 percentage points. Accounting for endogeneity turns the penalty into a small but statistically significant premium of $5 \%$.

Though the RLMS questionnaire is extensive and covers various aspects of economic behaviour, we are aware of that that our instruments may not fully capture the effect of unobservables. Many other personal characteristics can influence an individual's choice for the

${ }^{17}$ For the estimation, we used movestay and mspredict Stata modules developed by M.Lokshin and Z.Sajaia (Lokshin, M. and Z.Sajaia (2004) "Maximum likelihood estimation of endogenous switching regression models”, Stata Journal, Vol.4, Number 3, pp. 282-289). 
public sector, among which individual tastes, family background, occupational prestige are most likely candidates. Moreover, the estimation procedure assumes joint normality of the error terms in all equations. If the joint distribution of the error terms is non-normal, the estimated coefficients of wage equations could be severely biased and the estimated gaps would be incorrect. To overcome this potential problem we apply alternative method - fixed effects estimation.

\section{Inter-Sectoral Flows and Premium for the Sector Change}

This section investigates labour flows within and between the sectors as well as their interaction with the pools of unemployed and those out of labor force. We also estimate economic returns to the inter-sectoral transitions. This section relies on the RLMS data.

\section{Transition probabilities}

Smaller fraction of short-tenured workers (Table 1) is itself indicative for low inflows of the workforce into the public sector and low outflows from it. However, this summary measure tells us little about the sources of workers coming to the public sector and the destinations of those who leave it. In order to answer these questions we divided all the respondents into four groups: employed in the public sector; employed in the private sector; unemployed and those out of labour force. Mobility diagram in Figure 4 depicts transitions between these four groups as well job changes within the two sectors of employment. We look at all consecutive years within the period 2000-03 and then pool the estimates.

Public sector workers leaving their jobs are more likely to find new jobs in the private sector (7\%) than to land in the public sector once again (4\%). For private sector workers, the reverse is true: majority of movers find new jobs in the same sector while only a minor fraction of leavers moves into to the public sector. The public sector seems to be isolated from the pool of unemployment. On the one hand, workers leaving the public sector hardly ever end up in unemployment. On the other hand, the public sector rarely recruits the unemployed and interacts (through inflows and outflows) mostly with economically inactive population. The estimated sectoral wage differentials can explain low attractiveness of jobs in the public sector and, consequently, low inflows into this sector. However, low outflows from the public sector are a puzzle. One may assume there exist some additional unobservable advantages for employment in this sector. Alternatively, we may speculate that long work experience in the public sector stigmatises workers thus complicating their mobility into the commercial sector. 
During the period under consideration 210 individuals (7.1\% of all public sector workers) moved from the public to the private sector. Another 226 individuals (2.4\% of all private sector workers) moved in the opposite direction. The wage change occurring with the sector change ceteris paribus can be viewed as an effect of the sector switch. Thus we can use fixed effects model and estimate the following equation:

$$
\operatorname{Ln}\left(\text { Wage }_{i t}\right)=\alpha_{i}+\beta X_{i t}+s D_{i t}+\varepsilon_{i t}
$$

where $\alpha_{i}$ is individual fixed effect which reflects the impact of all unobservable personal characteristics which do not change over time. X's are the same as in OLS and SR regressions except gender, region and settlement type, which are in our data constant over time (the RLMS does not follow respondents who move to another locations).

Fixed effects model has two important advantages. First, returns to sector mobility are estimated only for those who have really switched the sector. Second, it effectively solves the endogeneity problem under the assumption that sector choice is correlated with unobservable but constant (fixed) personal characteristics.

Estimates from the fixed effects model are presented in the last column of Table 2a. We calculated the wage gaps for the whole sample and separately for men and women. Further splitting of the sample critically diminishes number of sector switchers. As shown in the table, moving to a job in the private sector might be extremely beneficial for public sector workers. Both men and women gain $20 \%$ in earnings when moving for the private sector. The gain is lower than it is suggested by the OLS estimates but is comparable to the SR estimates.

As comparison of all the estimates reveals, about a half of the unadjusted wage differential can be explained by observed and unobserved worker and job characteristics. Introducing additional controls lowers the wage gap. At least part of the wage differential is compensatory. However, extensive sets of controls still leave significant unexplained negative wage differential for public sector workers suggesting persistent violation of the "equal pay for equal work " principle.

\section{Public-Private Wage Gap on the Country “Map”}

The existing framework of wage-setting in the public sector implies the positive relationship between the size of the wage gap and the level of regional development. This machinery produces a "layered cake": there are basic or mandatory ingredients and there are supplements that can be added if available. In relatively successful regions this 'cake' has more layers (including supplements - premia and bonuses) and the layers themselves are thicker. In less successful, the wage consists from the basic (mandatory) part only. In this section of the paper we relate the wage gap to per capita gross regional product (GRP) and regional unemployment. 
One of the key advantages of the NOBUS sample is in its representativeness for 46 regions spread across the whole Russian territory. This allows us going beyond the national level and estimating the wage gap for each of these regions. We employ propensity score matching (with kernel matching) and bootstrapping procedure to obtain estimates and standard errors of the wage gap separately for each region. Non-parametric matching methods propose alternative (to the regression framework) solution to the problem of selection into the public sector. Having a job in the public sector can be viewed as a specific 'treatment' applied to an employee that drives actual wages of the 'treated' away from the wages they could alternatively have if they were in the private sector. The basic idea behind this is to construct a 'control' group of private sector workers who are similar to public sector workers in all relevant pre-treatment characteristics. Observed wage differences between the control and the treatment groups can be attributed to the sector effect. Propensity score matching (PSM) methods are based on the calculation of the propensity score which is the conditional probability to participate in treatment group given all relevant observable characteristics. As a probability it takes values from 0 to 1 . Values of the propensity score for each individual are computed using probit or logit models. Thus, the propensity score is a compressed one-dimensional measure of individual differences that rule the selection into the public sector. The next step is to compare a wage of each public sector worker with a wage of a private sector worker with similar value of the propensity score and to average such differences across all public sector workers.

The kernel matching uses all those employed in the private sector of the relevant region as a comparison group for each public sector employee. In this case the counterfactual wage is constructed as a weighted average where weights depend on the distance in propensity scores. The higher weight is attributed to individuals with similar or close propensity scores and those with distant propensity scores receive lower weights.

Our estimates show that in all but one (Dagestan) out of 46 regions, wages are markedly higher in the private sector. In nine (of 46 in the sample) regions the gap is not significantly different from zero. Three out of these 9 regions are located in the less developed Southern Federal District. In the remaining 36 regions the gap is significantly positive. Note that in 21 regions (slightly more than $50 \%$ of all regions in the sample) the gap exceeds $20 \%$.

Figures 5 and 6 plot the wage gap against the per capita gross regional product (GRP) and the regional unemployment rate. Figure 5 excludes two regions (Moscow city and Tyumen' oblast') in which per capita GRP levels are more than two times higher than the national average. Both regions appear as outliers in descriptive statistics and lay far away from the regression line drawn for all other regions. Both regions play an exceptional role in the Russian economy due to the capital status (Moscow) or due to the concentration of oil extraction (Tyumen'). In the both cases, regional and local budgets enjoy extra opportunities to raise compensations for public 
sector workers above average nominal levels. However, even here public sector workers are significantly underpaid (against the private sector control group) and the magnitude of the wage gap is pretty similar to the national average gap.

Figure 5 clearly shows that in the poorest regions wages of comparable workers in the public sector and private sector are almost the same. The sectoral gap increases as per capita GRP grows. On average, the $10 \%$ increase in per capita GRP leads to 1.1 percentage point increase in the private sector premium. These results well illustrate the fact that the existing payment system in the public sector is linked to the possibilities of the weakest regions and penalizes workers in the richer regions.

The relationship between wage gaps and regional unemployment rates is even more acute. Public sector workers are stronger penalized in the regions with low unemployment. Figure 6 shows that 1 percentage point increase in the regional unemployment rate narrows the gap by 1.5 percentage points. Higher regional unemployment restrains wage growth in the private sector pressing the wages down to the levels set by the government in the public sector.

Our analysis in this section leads to important policy implications. First, it suggests that rising public sector wages by the same amount in all regions (as it has been the governmental policy) is not a reasonable strategy. Such a wage shift may narrow a negative gap in some regions while turning the penalty into a premium in other regions. In its turn, large positive gaps may increase labour costs in the private sector, suppress local employment and generate extra unemployment by pushing up the reservation wages. It will mostly be the case for the poorest regions, which are already grappled with low employment levels and high unemployment rates. The consequences of a uniform increase in the public sector wages will be even more profound if we account for spillover effects in the private sector.

Italy provides a good example of differences in the public-private wage gaps under centralized wage-setting in a country with heterogeneous regional development. The wagesetting for the public sector in Italy is based on collective bargaining but the agreed wage rates do not vary across regions and are not adjusted for situation at the local labour markets. As a result, the highest positive public-private pay differential is in the South. In the North, the differential is still positive but considerably smaller in magnitude. Therefore, differences in wage gaps may be said to act as a redistributive mechanism from wealthier North to the economically more backward South. Negative consequence of huge wage differential in the South is that it suppresses the private sector in southern provinces by discouraging job creation and crowding out jobs into the informal sector. ${ }^{18}$ Analyzing the case of Italy, Dell'Aringa et al (2005)

\footnotetext{
${ }^{18}$ Alesina A., Danninger S. and Rostagno M. "Redistribution Through Public Employment: The Case of Italy”, NBER Working Paper No.7387, Oct 1999; Dell’Aringa C., C.Lucifora and
} 
conclude: «This system (of pay determination in the public sector - Authors) would benefit from more decentralization, if local labor market conditions have to play a role. National agreements do not need to be discarded, but they should (at least) be less important in determining pay increases: ideally they could be a point of reference with some further (flexible) negotiations at the local level». ${ }^{19}$ This conclusion seems to apply to Russia as well.

\section{Conclusions and Policy Implications}

The main conclusion from our study is that wages for the majority of public sector employees should be decentralized and should be tied to the functioning of regional labor markets. The negotiations of the education and public health workers trade unions with regional administrations may be one such mechanism of tying wages to the labor market situation. Yet, so far few regions have chosen not to base the wages of public sector employees on the unified wage scale, although they are allowed to do so according to the federal law.

Besides, labor compensation is closely linked to employment. A more rigid and decentralized pegging of the public sector wages to those in the private sector (that is, creation of institutional conditions for eliminating the gap) would require more flexibility in employment. The public sector should shed part of its labor force by getting rid of redundant people and abandoning the functions of social protection that are not inherent in it. In other words the wage reform must become an element in a systemic reform of Russian public sector.

F.Origo. Public Sector Pay and Regional Competitiveness: A First Look at Regional PublicPrivate Wage Differentials in Italy. IZA DP No.1828, October 2005.

${ }^{19}$ Dell’Aringa C., C.Lucifora and F.Origo. Op.cit. p.38. 
Appendix: Figures and Tables

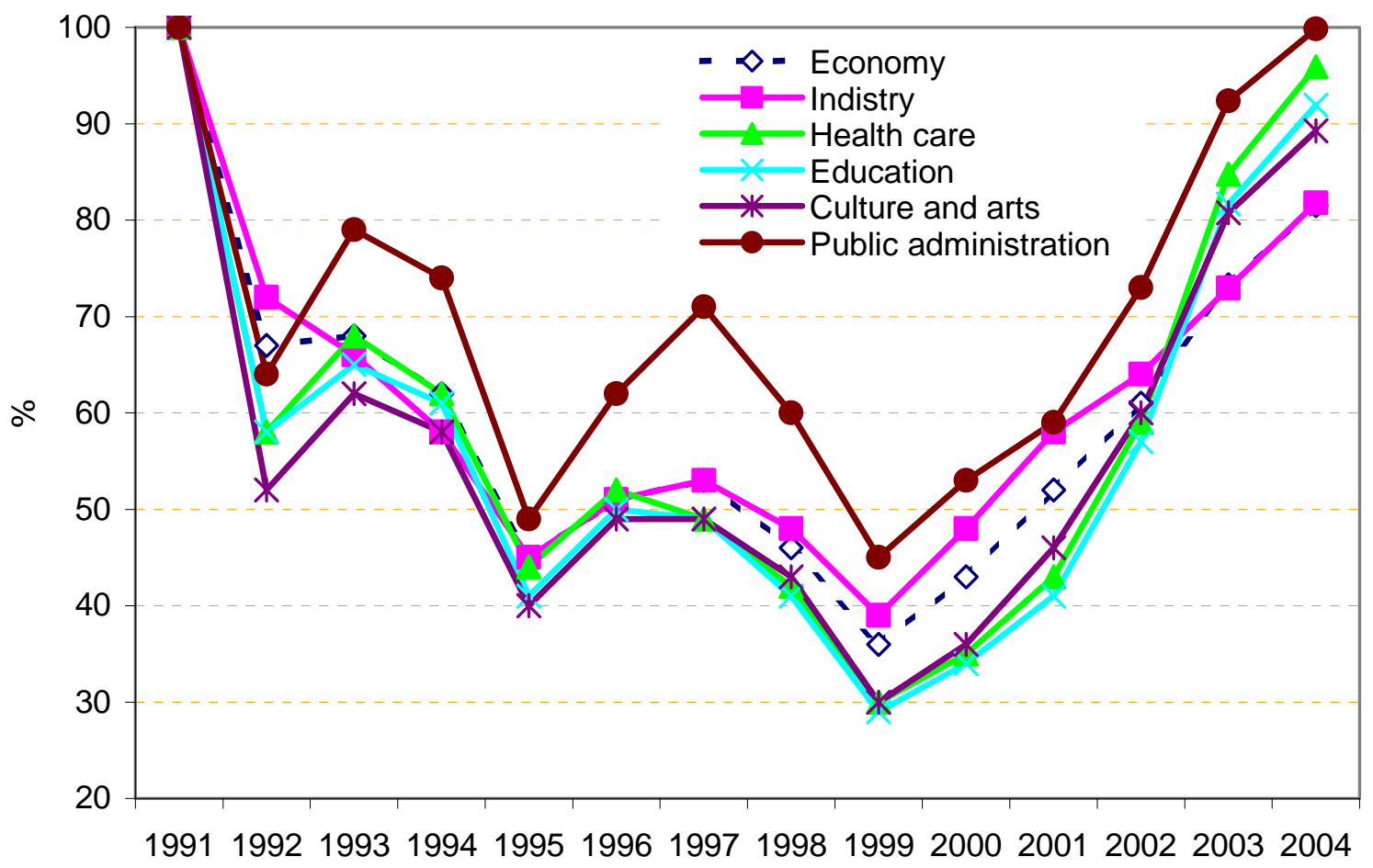

Figure 1. Real wages by industry, 1991=100\%

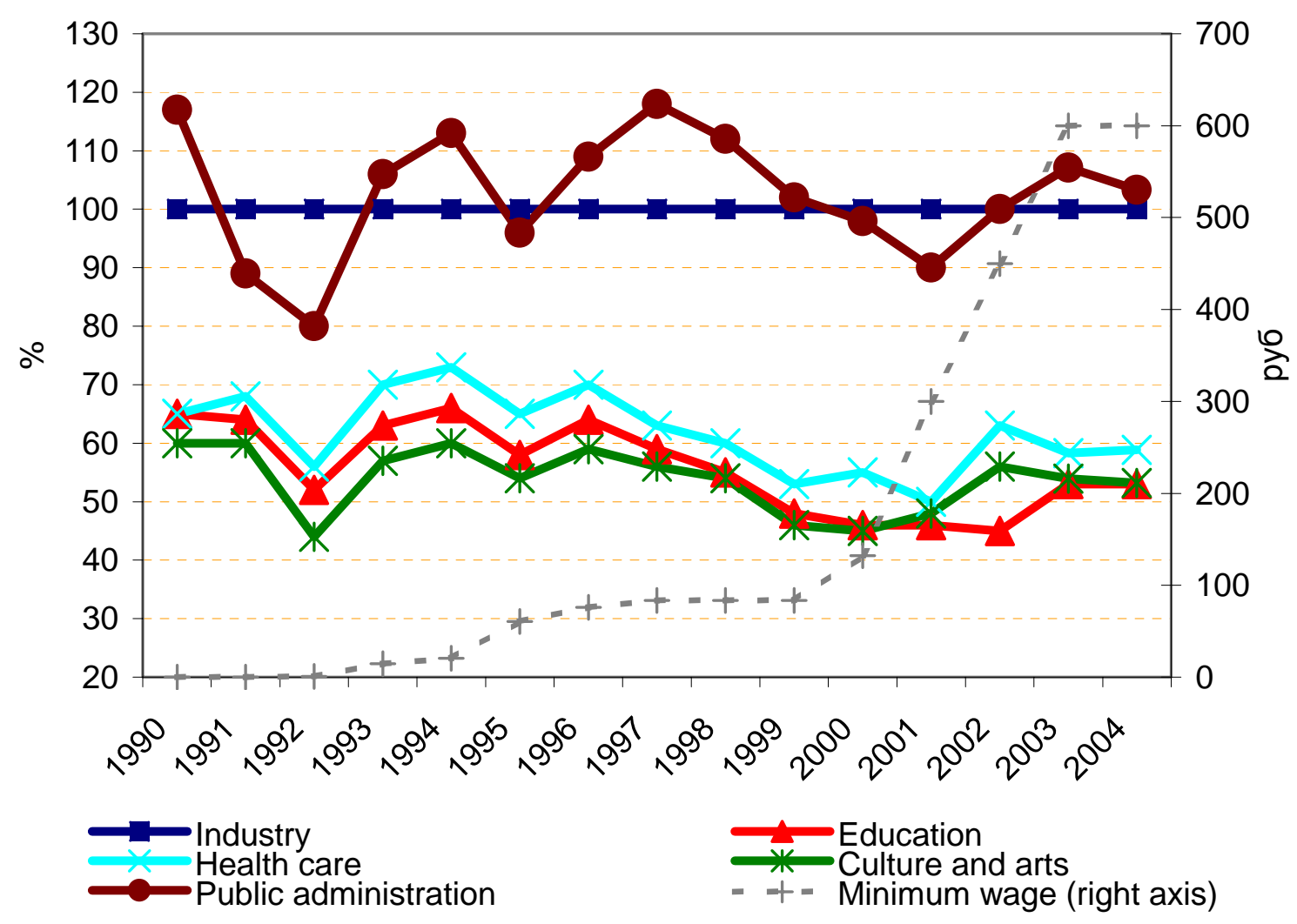

Figure 2 Average wages in the sub-sectors of the public sector relative to average wages in industry, 1990-2004 


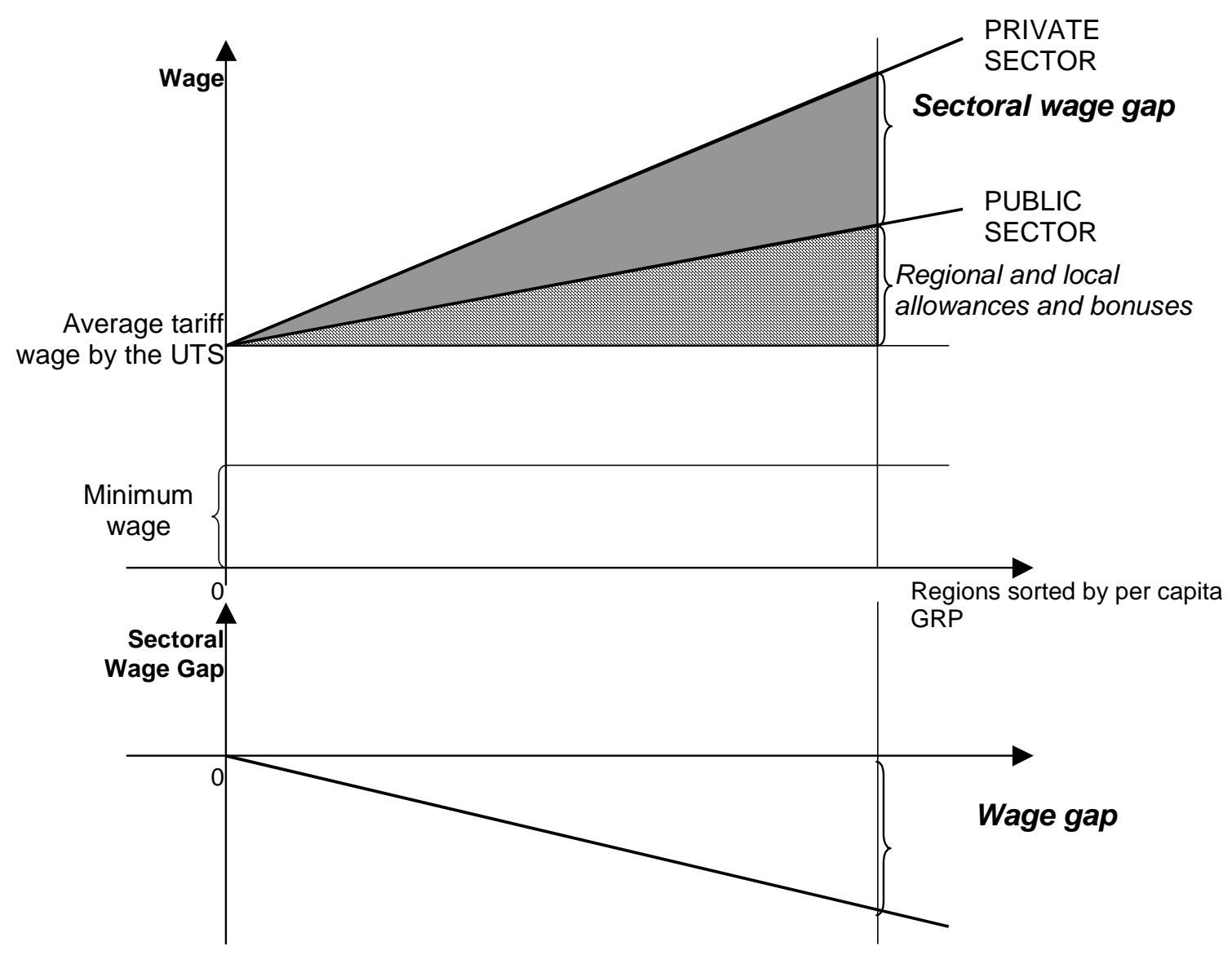

Figure 3. Wage-setting in the Public Sector

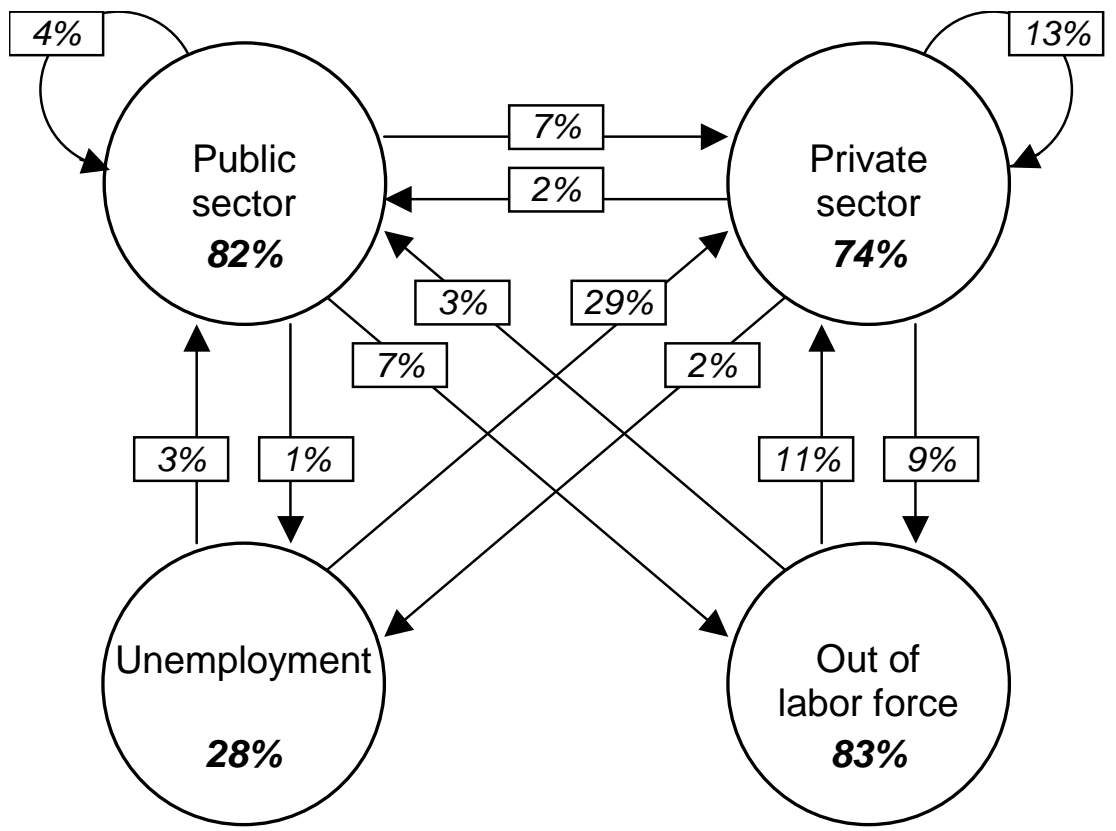

Figure 4. Labor Mobility 


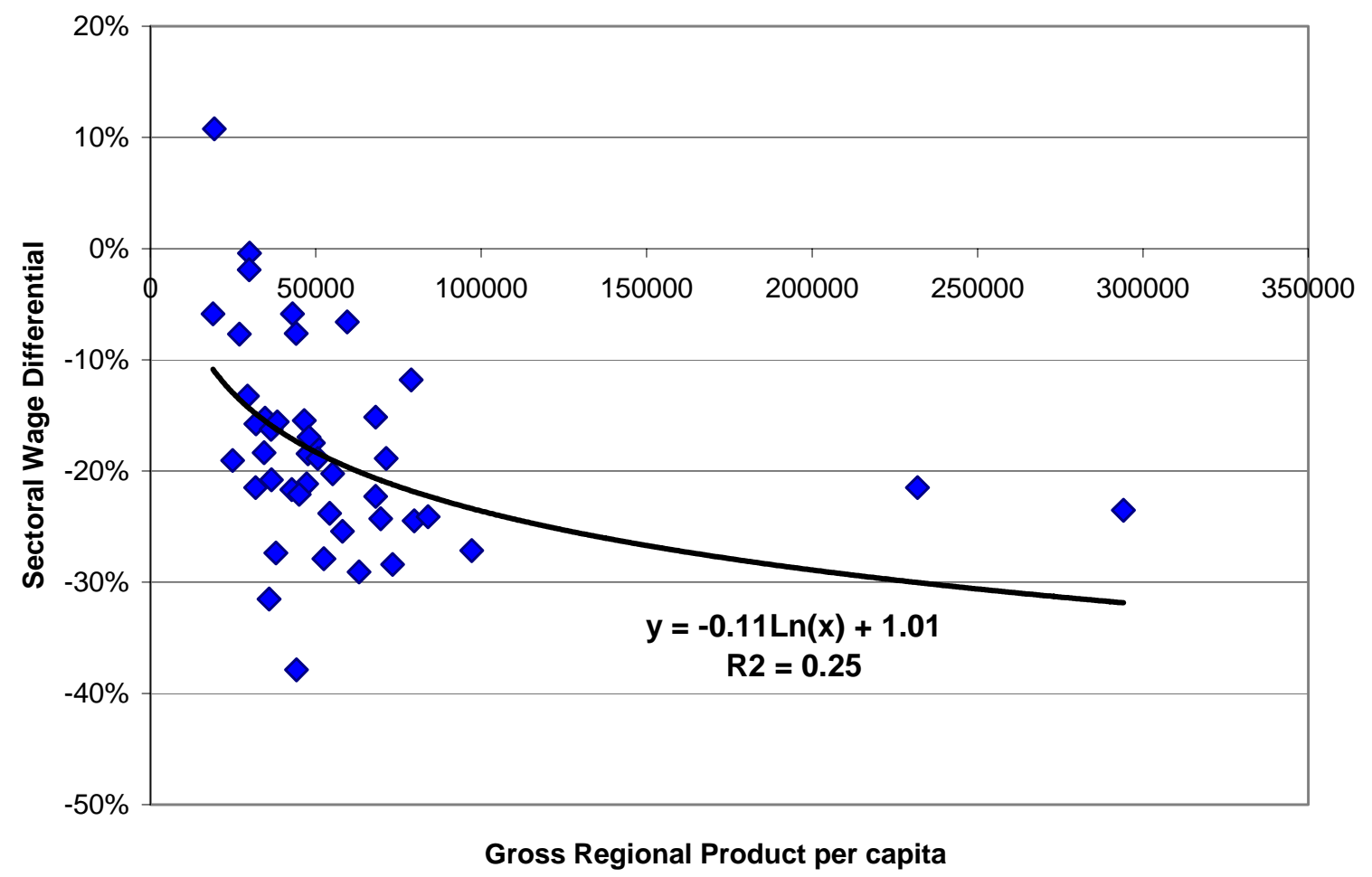

Figure 5. The Public-Private Wage Gaps and Regional Development

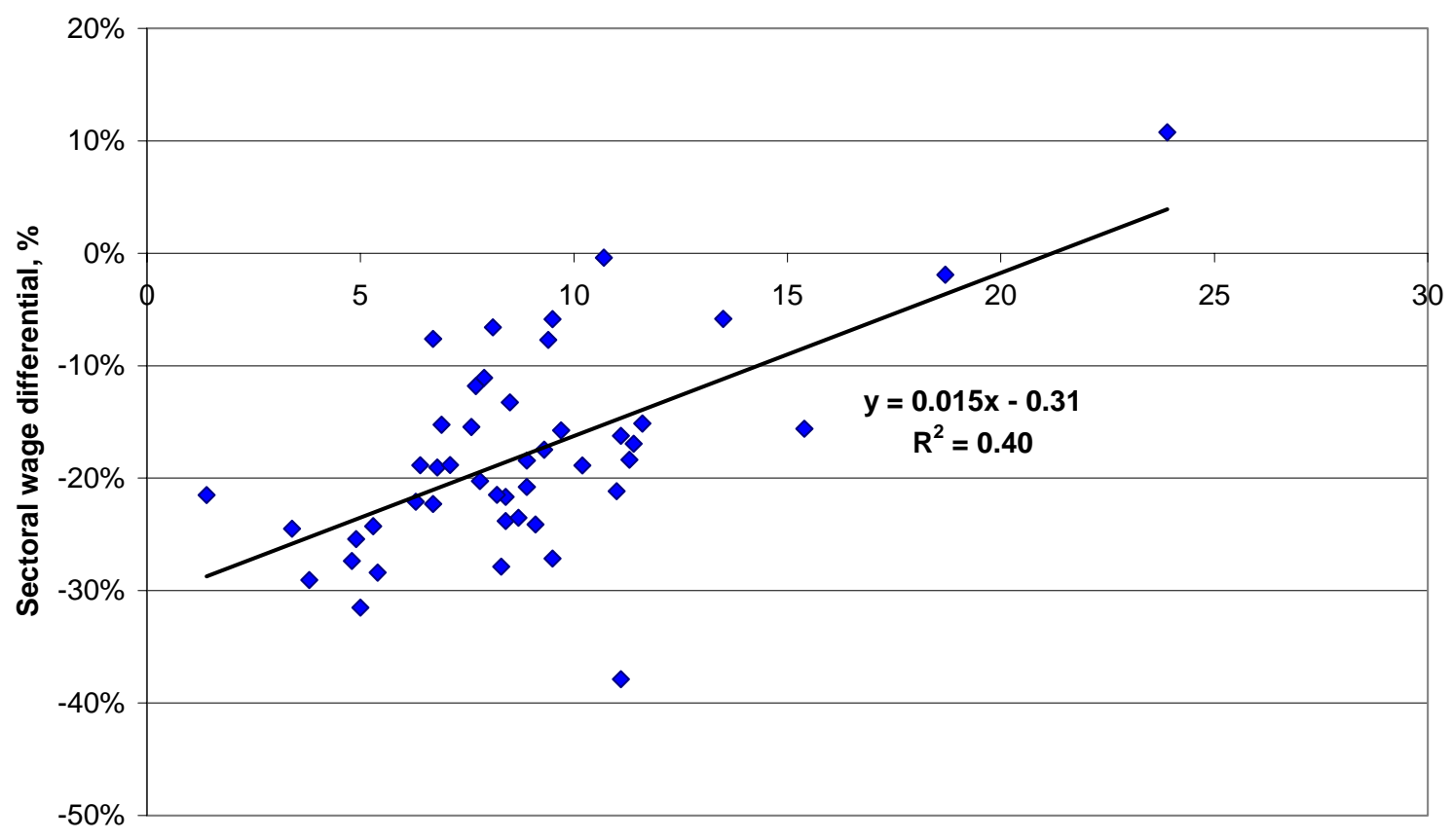

Regional unemployment rate, \%

Figure 6. The Public-Private Wage Gaps and Regional Unemployment 
Table 1. Descriptive statistics

\begin{tabular}{|c|c|c|c|c|c|c|c|c|c|c|c|c|c|c|c|c|c|c|}
\hline & \multicolumn{6}{|c|}{ All } & \multicolumn{6}{|c|}{ Public sector } & \multicolumn{6}{|c|}{ Private sector } \\
\hline & 2000 & 2001 & 2002 & 2003 & 2003 & \multirow{2}{*}{\begin{tabular}{|c|}
2004 \\
RLMS \\
\end{tabular}} & 2000 & 2001 & 2002 & 2003 & 2003 & \multirow{2}{*}{\begin{tabular}{|c|}
2004 \\
RLMS \\
\end{tabular}} & \multirow{2}{*}{\begin{tabular}{|c|}
2000 \\
RLMS \\
\end{tabular}} & \multirow{2}{*}{\begin{tabular}{|c|}
2001 \\
RLMS \\
\end{tabular}} & \multirow{2}{*}{\begin{tabular}{|c|}
2002 \\
RLMS \\
\end{tabular}} & \multirow{2}{*}{\begin{tabular}{|c|}
2003 \\
NOBUS \\
\end{tabular}} & \multirow{2}{*}{2003} & \multirow{2}{*}{\begin{tabular}{|c|}
2004 \\
RLMS \\
\end{tabular}} \\
\hline & RLMS & RLMS & RLMS & NOBUS & RLMS & & RLMS & RLMS & RLMS & NOBUS & RLMS & & & & & & & \\
\hline $\begin{array}{l}\text { Employment by sector, \% of total } \\
\text { employment }\end{array}$ & 100.0 & 100.0 & 100.0 & 100.0 & 100.0 & 100.0 & 25.4 & 25.1 & 25.1 & 26.9 & 25.8 & 25.8 & 74.6 & 75.0 & 74.9 & 73.1 & 74.2 & 74.3 \\
\hline Female , \% & 52.9 & 53.6 & 53.7 & 53.1 & 54.4 & 54.2 & 74.7 & 76.9 & 74.6 & 75.1 & 76.4 & 77.6 & 45.2 & 45.8 & 46.8 & 45.0 & 46.8 & 46.0 \\
\hline \multicolumn{19}{|l|}{ Education, \% } \\
\hline No education. primary education & 0.8 & 0.6 & 0.4 & 0.9 & 0.4 & 0.3 & 0.4 & 0.4 & 0.4 & 0.8 & 0.3 & 0.3 & 0.9 & 0.7 & 0.4 & 1.0 & 0.4 & 0.4 \\
\hline Incomplete secondary + vocational & 4.0 & 3.9 & 3.5 & 3.9 & 4.3 & 3.7 & 2.0 & 2.0 & 2.3 & 2.2 & 2.5 & 1.9 & 4.7 & 4.5 & 3.9 & 4.5 & 5.0 & 4.3 \\
\hline Incomplete secondary & 8.2 & 7.5 & 7.7 & 7.0 & 7.4 & 7.3 & 3.5 & 4.7 & 5.0 & 4.3 & 4.9 & 4.2 & 9.8 & 8.5 & 8.5 & 8.0 & 8.3 & 8.3 \\
\hline Complete secondary + vocational & 16.6 & 17.3 & 17.2 & 8.4 & 17.0 & 17.9 & 8.9 & 7.9 & 8.7 & 4.7 & 9.4 & 10.8 & 19.2 & 20.4 & 20.0 & 9.8 & 19.6 & 20.4 \\
\hline Complete secondary & 22.0 & 22.1 & 22.0 & 20.3 & 21.4 & 21.2 & 12.6 & 14.1 & 13.0 & 12.9 & 12.4 & 12.5 & 25.2 & 24.7 & 25.0 & 23.1 & 24.5 & 24.2 \\
\hline College & 26.0 & 24.6 & 25.5 & 34.2 & 25.0 & 25.2 & 33.1 & 29.7 & 31.5 & 35.0 & 31.1 & 29.9 & 23.5 & 22.9 & 23.5 & 34.0 & 22.9 & 23.5 \\
\hline Some university & & & & 3.6 & & & & & & 4.2 & & & & & & 3.4 & & \\
\hline University & 22.5 & 24.1 & 23.8 & 21.6 & 24.5 & 24.4 & 39.5 & 41.3 & 39.2 & 36.1 & 39.5 & 40.4 & 16.7 & 18.4 & 18.7 & 16.3 & 19.3 & 18.9 \\
\hline \multicolumn{19}{|l|}{ Occupation, \% } \\
\hline Managers & 5.4 & 6.8 & 6.0 & 2.6 & 3.9 & 4.1 & 5.3 & 8.3 & 6.4 & 4.4 & 2.5 & 3.1 & 5.4 & 6.2 & 5.9 & 2.0 & 4.4 & 4.4 \\
\hline Professionals & 17.9 & 18.5 & 17.3 & 14.8 & 19.1 & 18.4 & 41.9 & 43.1 & 37.9 & 28.3 & 41.5 & 41.8 & 9.7 & 10.3 & 10.4 & 9.9 & 11.3 & 10.2 \\
\hline Associate professionals & 16.0 & 15.4 & 16.8 & 20.3 & 16.5 & 16.9 & 26.8 & 22.5 & 26.9 & 35.5 & 25.5 & 25.5 & 12.4 & 13.0 & 13.5 & 14.8 & 13.3 & 13.9 \\
\hline Clerks & 6.0 & 5.9 & 6.7 & 5.8 & 6.8 & 6.3 & 4.4 & 4.2 & 4.9 & 7.9 & 5.6 & 4.0 & 6.5 & 6.5 & 7.4 & 5.1 & 7.3 & 7.1 \\
\hline Service workers & 8.7 & 8.6 & 8.7 & 14.4 & 9.3 & 9.2 & 10.9 & 10.6 & 10.4 & 6.4 & 10.9 & 10.6 & 8.0 & 7.9 & 8.2 & 17.3 & 8.8 & 8.8 \\
\hline Skilled agricultural workers & 0.7 & 0.5 & 0.4 & 4.1 & 0.5 & 0.4 & 0.1 & 0.0 & 0.1 & 0.1 & 0.2 & 0.2 & 0.9 & 0.6 & 0.5 & 5.6 & 0.6 & 0.5 \\
\hline Craft workers & 14.7 & 13.7 & 13.9 & 16.5 & 13.5 & 14.1 & 1.1 & 1.2 & 2.1 & 2.0 & 1.7 & 2.0 & 19.3 & 17.9 & 17.8 & 21.9 & 17.6 & 18.3 \\
\hline Operators and assemblers & 18.9 & 18.1 & 17.8 & 6.8 & 17.3 & 18.2 & 3.6 & 3.0 & 3.4 & 1.9 & 3.4 & 3.5 & 24.2 & 23.1 & 22.6 & 8.6 & 22.2 & 23.3 \\
\hline Elementary occupations & 11.7 & 12.6 & 12.3 & 14.5 & 13.1 & 12.4 & 6.1 & 7.0 & 7.9 & 13.5 & 8.8 & 9.3 & 13.6 & 14.5 & 13.8 & 14.9 & 14.6 & 13.5 \\
\hline Rural, \% & 23.0 & 21.1 & 21.3 & 23.9 & 21.8 & 21.3 & 23.7 & 23.4 & 23.6 & 27.2 & 25.4 & 24.8 & 22.8 & 20.4 & 20.5 & 22.7 & 20.5 & 20.1 \\
\hline \multicolumn{19}{|l|}{ Age, \% } \\
\hline under 30 & 25.3 & 26.4 & 27.4 & 20.1 & 26.9 & 26.1 & 28.5 & 28.1 & 26.5 & 15.9 & 26.5 & 24.4 & 24.1 & 25.9 & 27.7 & 21.7 & 27.1 & 26.7 \\
\hline $30-40$ & 23.5 & 24.5 & 23.0 & 25.5 & 23.2 & 24.9 & 23.3 & 23.8 & 25.8 & 25.0 & 25.4 & 27.0 & 23.5 & 24.7 & 22.1 & 25.7 & 22.4 & 24.2 \\
\hline $40-50$ & 30.1 & 29.0 & 28.9 & 30.5 & 28.4 & 27.3 & 28.2 & 28.4 & 27.8 & 32.0 & 27.5 & 25.0 & 30.8 & 29.3 & 29.2 & 29.9 & 28.8 & 28.1 \\
\hline $50+$ & 21.2 & 20.1 & 20.7 & 23.9 & 21.5 & 21.8 & 20.0 & 19.8 & 19.9 & 27.2 & 20.6 & 23.7 & 21.5 & 20.2 & 21.0 & 22.7 & 21.8 & 21.1 \\
\hline Average tenure, years & 7.7 & 8.0 & 7.5 & & 7.6 & 7.6 & 8.1 & 8.8 & 8.4 & & 8.7 & 9.3 & 7.5 & 7.7 & 7.3 & & 7.3 & 7.0 \\
\hline $\begin{array}{l}\text { Fraction of workers with less than } 1 \text { year of } \\
\text { tenure. } \%\end{array}$ & 16.7 & 18.0 & 18.7 & 13.5 & 17.9 & 18.1 & 11.8 & 11.2 & 12.1 & 8.5 & 10.5 & 9.9 & 18.3 & 20.3 & 20.9 & 15.3 & 20.5 & 21.0 \\
\hline Average working week & 43.2 & 43.5 & 43.3 & 41.0 & 43.3 & 43.5 & 39.2 & 39.6 & 39.6 & 38.6 & 39.4 & 40.0 & 44.5 & 44.8 & 44.6 & 41.9 & 44.6 & 44.8 \\
\hline $\begin{array}{l}\text { Fraction of workers engaged in intensive } \\
\text { manual work. \% }\end{array}$ & 27.3 & 29.0 & 28.3 & & - & - & 10.9 & 13.5 & 13.0 & & - & - & 32.9 & 34.1 & 33.5 & & - & - \\
\hline
\end{tabular}




\begin{tabular}{|c|c|c|c|c|c|c|c|c|c|c|c|c|c|c|c|c|c|c|}
\hline & \multicolumn{6}{|c|}{ All } & \multicolumn{6}{|c|}{ Public sector } & \multicolumn{6}{|c|}{ Private sector } \\
\hline & 2000 & 2001 & 2002 & 2003 & 2003 & 2004 & 2000 & 2001 & 2002 & 2003 & 2003 & 2004 & 2000 & 2001 & 2002 & 2003 & 2003 & 2004 \\
\hline & RLMS & RLMS & RLMS & NOBUS & RLMS & RLMS & RLMS & RLMS & RLMS & NOBUS & RLMS & RLMS & RLMS & RLMS & RLMS & NOBUS & RLMS & RLMS \\
\hline $\begin{array}{l}\text { Fraction of working time spent on intensive } \\
\text { manual work (for those engaged in intensive } \\
\text { manual work), \% }\end{array}$ & 47.9 & 44.8 & 42.7 & - & - & - & 31.9 & 33.5 & 31.7 & - & - & - & 49.7 & 46.3 & 44.1 & - & - & - \\
\hline Average wage, current rubles & 1702 & 2559 & 3407 & 3438 & 4250 & 5247 & 1146 & 1671 & 2452 & 2949 & 2853 & 3600 & 1891 & 2856 & 3727 & 3621 & 4735 & 5818 \\
\hline Average wage, September 2000 rubles & 1661 & 2073 & 2385 & & 2620 & 2885 & 1119 & 1356 & 1722 & & 1762 & 1985 & 1846 & 2313 & 2607 & & 2918 & 3198 \\
\hline Regular secondary employment, \% & 5.2 & 5.5 & 5.1 & 3.0 & 5.3 & 5.0 & 7.9 & 8.2 & 8.4 & 5.6 & 8.5 & 8.4 & 4.3 & 4.5 & 4.0 & 2.1 & 4.3 & 3.8 \\
\hline Supplementary occasional work, \% & 6.2 & 6.2 & 5.1 & 1.0 & 5.4 & 4.4 & 5.8 & 6.7 & 5.2 & 1.0 & 4.9 & 4.0 & 6.4 & 6.0 & 5.0 & 1.0 & 5.6 & 4.6 \\
\hline Pensioners, \% & 12.5 & 11.6 & 11.9 & 12.1 & 12.9 & 12.5 & 17.0 & 15.8 & 16.3 & 18.4 & 16.7 & 17.9 & 10.9 & 10.1 & 10.5 & 9.7 & 11.6 & 10.6 \\
\hline$N$ & 3758 & 4263 & 4518 & 46622 & 4472 & 4525 & 954 & 1068 & 1134 & 12530 & 1153 & 1165 & 2804 & 3195 & 3384 & 34092 & 3319 & 3360 \\
\hline
\end{tabular}

Note: The sample is restricted to individuals aged 15-72 employed in the corporative sector. 
Table 2a. Public-private wage gap (in percent of the private sector wages), RLMS

\begin{tabular}{|c|c|c|c|c|c|c|c|c|}
\hline & $\begin{array}{l}\text { Raw } \\
\text { data }\end{array}$ & & & $\begin{array}{r}0 \\
\text { (augn }\end{array}$ & ted) & $\begin{array}{c}\text { SR } \\
\text { (basic) }\end{array}$ & $\begin{array}{c}\text { SR } \\
\text { (augmented) }\end{array}$ & FE \\
\hline & $\%$ & $\%$ & R2 & $\%$ & R2 & $\%$ & $\%$ & $\%$ \\
\hline All & $-39 \%$ & $-28 \%$ & 0.44 & $-26 \%$ & 0.46 & $-18 \%$ & $-16 \%$ & $-18 \%$ \\
\hline $\begin{array}{l}2000 \\
2001 \\
2002 \\
2003\end{array}$ & $\begin{array}{l}-39 \% \\
-41 \% \\
-34 \% \\
-40 \% \\
\end{array}$ & $\begin{array}{l}-28 \% \\
-32 \% \\
-22 \% \\
-28 \% \\
\end{array}$ & $\begin{array}{l}0.39 \\
0.40 \\
0.42 \\
0.45 \\
\end{array}$ & $\begin{array}{l}-28 \% \\
-30 \% \\
-19 \% \\
-26 \% \\
\end{array}$ & $\begin{array}{l}0.42 \\
0.42 \\
0.44 \\
0.47\end{array}$ & $\begin{array}{l}-20 \% \\
-24 \% \\
-11 \% \\
-19 \% \\
\end{array}$ & $\begin{array}{c}-19 \% \\
-22 \% \\
-8 \% \\
-17 \% \\
\end{array}$ & \\
\hline \begin{tabular}{|l|} 
Males \\
Females \\
\end{tabular} & $\begin{array}{l}-29 \% \\
-32 \% \\
\end{array}$ & $\begin{array}{l}-27 \% \\
-30 \% \\
\end{array}$ & $\begin{array}{l}0.40 \\
0.43 \\
\end{array}$ & $\begin{array}{l}-27 \% \\
-27 \% \\
\end{array}$ & $\begin{array}{l}0.43 \\
0.45 \\
\end{array}$ & $\begin{array}{l}-15 \% \\
-19 \% \\
\end{array}$ & $\begin{array}{l}-14 \% \\
-17 \% \\
\end{array}$ & \begin{tabular}{|l|}
$-19 \%$ \\
$-18 \%$ \\
\end{tabular} \\
\hline $\begin{array}{r}\text { under } 30 \\
30-40 \\
40-50 \\
50+\end{array}$ & $\begin{array}{l}-46 \% \\
-39 \% \\
-37 \% \\
-32 \% \\
\end{array}$ & $\begin{array}{l}-36 \% \\
-25 \% \\
-24 \% \\
-26 \% \\
\end{array}$ & $\begin{array}{l}0.47 \\
0.44 \\
0.45 \\
0.43 \\
\end{array}$ & $\begin{array}{l}-35 \% \\
-23 \% \\
-23 \% \\
-24 \% \\
\end{array}$ & $\begin{array}{l}0.49 \\
0.46 \\
0.47 \\
0.45 \\
\end{array}$ & $\begin{array}{l}-29 \% \\
-18 \% \\
-14 \% \\
-11 \% \\
\end{array}$ & $\begin{array}{c}-28 \% \\
-16 \% \\
-12 \% \\
-9 \% \\
\end{array}$ & \\
\hline \begin{tabular}{|r|} 
Settlement type \\
Moscow $+\mathrm{SPb}$ \\
regional capitals \\
towns \\
rural area + urban-type \\
settlements \\
\end{tabular} & $\begin{array}{l}-55 \% \\
-32 \% \\
-42 \% \\
-34 \%\end{array}$ & $\begin{array}{l}-39 \% \\
-34 \% \\
-31 \% \\
-10 \%\end{array}$ & $\begin{array}{l}0.38 \\
0.43 \\
0.52 \\
0.36\end{array}$ & $\begin{array}{l}-37 \% \\
-33 \% \\
-31 \% \\
-10 \%\end{array}$ & $\begin{array}{l}0.40 \\
0.45 \\
0.54 \\
0.39\end{array}$ & $\begin{array}{l}-39 \% \\
-28 \% \\
-28 \% \\
5 \%\end{array}$ & $\begin{array}{l}-35 \% \\
-26 \% \\
-26 \% \\
6 \%\end{array}$ & \\
\hline \begin{tabular}{|r|} 
Education \\
Incomplete secondary and less \\
Complete secondary \\
College \\
University \\
\end{tabular} & $\begin{array}{l}-57 \% \\
-52 \% \\
-46 \% \\
-45 \% \\
\end{array}$ & $\begin{array}{l}-27 \% \\
-33 \% \\
-23 \% \\
-29 \% \\
\end{array}$ & $\begin{array}{l}0.48 \\
0.44 \\
0.40 \\
0.40 \\
\end{array}$ & $\begin{array}{l}-24 \% \\
-31 \% \\
-21 \% \\
-28 \% \\
\end{array}$ & $\begin{array}{l}0.50 \\
0.46 \\
0.43 \\
0.42 \\
\end{array}$ & $\begin{array}{l}-19 \% \\
-26 \% \\
-14 \% \\
-18 \% \\
\end{array}$ & $\begin{array}{l}-16 \% \\
-24 \% \\
-13 \% \\
-16 \% \\
\end{array}$ & \\
\hline \begin{tabular}{|r|} 
Occupation \\
Managers \\
Professionals \\
Associate professionals \\
Clerks \\
Service workers \\
Craft workers \\
Operators and assemblers \\
Elementary occupations \\
\end{tabular} & $\begin{array}{l}-46 \% \\
-45 \% \\
-47 \% \\
-31 \% \\
-22 \% \\
-67 \% \\
-49 \% \\
-62 \% \\
\end{array}$ & $\begin{array}{l}-30 \% \\
-28 \% \\
-30 \% \\
-24 \% \\
-33 \% \\
-42 \% \\
-27 \% \\
-37 \% \\
\end{array}$ & $\begin{array}{l}0.44 \\
0.42 \\
0.48 \\
0.48 \\
0.49 \\
0.37 \\
0.36 \\
0.47 \\
\end{array}$ & $\begin{array}{l}-26 \% \\
-26 \% \\
-29 \% \\
-22 \% \\
-30 \% \\
-38 \% \\
-23 \% \\
-35 \% \\
\end{array}$ & $\begin{array}{l}0.47 \\
0.45 \\
0.50 \\
0.50 \\
0.51 \\
0.41 \\
0.40 \\
0.49 \\
\end{array}$ & $\begin{array}{l}-16 \% \\
-16 \% \\
-21 \% \\
-20 \% \\
-16 \% \\
-33 \% \\
-18 \% \\
-29 \% \\
\end{array}$ & $\begin{array}{l}-16 \% \\
-14 \% \\
-19 \% \\
-16 \% \\
-17 \% \\
-22 \% \\
-11 \% \\
-25 \% \\
\end{array}$ & \\
\hline $\begin{array}{r}\text { Centre } \\
\text { North-West } \\
\text { South } \\
\text { Volga } \\
\text { Urals } \\
\text { Siberia } \\
\text { Far East }\end{array}$ & $\begin{array}{l}-45 \% \\
-56 \% \\
-43 \% \\
-30 \% \\
-31 \% \\
-23 \% \\
-24 \%\end{array}$ & $\begin{array}{l}-40 \% \\
-35 \% \\
-16 \% \\
-25 \% \\
-20 \% \\
-14 \% \\
-21 \%\end{array}$ & $\begin{array}{l}0.42 \\
0.51 \\
0.42 \\
0.45 \\
0.55 \\
0.50 \\
0.59\end{array}$ & $\begin{array}{l}-38 \% \\
-34 \% \\
-17 \% \\
-22 \% \\
-20 \% \\
-14 \% \\
-20 \%\end{array}$ & $\begin{array}{l}0.45 \\
0.53 \\
0.45 \\
0.49 \\
0.57 \\
0.53 \\
0.60\end{array}$ & $\begin{array}{l}-34 \% \\
-32 \% \\
-5 \% \\
-19 \% \\
-12 \% \\
-3 \% \\
-4 \%\end{array}$ & $\begin{array}{l}-33 \% \\
-28 \% \\
-5 \% \\
-17 \% \\
-8 \% \\
-2 \% \\
-2 \% *\end{array}$ & \\
\hline
\end{tabular}

Note: The basic specifications include the following variables: age, age squared, tenure, tenure squared, gender, marital status, education, occupation, duration of working week (log), firm size, settlement type, year, region, The augmented specifications additionally include secondary employment, fears of unemployment, non-pecuniary benefits.

* marks the estimates NON-significant at 5\% level. 
Table 2b. Public-private wage gap (in percent of the private sector wages), NOBUS

\begin{tabular}{|c|c|c|c|}
\hline & Raw data & OLS & SR \\
\hline All & $-19 \%$ & $-16 \%$ & $-17 \%$ \\
\hline \begin{tabular}{|l|} 
Males \\
Females
\end{tabular} & $\begin{array}{l}-8 \% \\
-11 \%\end{array}$ & $\begin{array}{l}-14 \% \\
-18 \%\end{array}$ & $\begin{array}{l}-17 \% \\
-17 \%\end{array}$ \\
\hline $\begin{array}{r}\text { under } 30 \\
30-40 \\
40-50 \\
50+ \\
\end{array}$ & $\begin{array}{l}-22 \% \\
-20 \% \\
-17 \% \\
-17 \% \\
\end{array}$ & $\begin{array}{l}-20 \% \\
-16 \% \\
-14 \% \\
-16 \% \\
\end{array}$ & $\begin{array}{l}-24 \% \\
-18 \% \\
-15 \% \\
-14 \% \\
\end{array}$ \\
\hline \begin{tabular}{|r|} 
Settlement type \\
large cities (more than 500000 residents) \\
medium-size cities (100000-500000 residents) \\
small towns, urban-type settlements \\
rural
\end{tabular} & $\begin{array}{l}-21 \% \\
-18 \% \\
-21 \% \\
2 \% * \\
\end{array}$ & $\begin{array}{c}-23 \% \\
-19 \% \\
-21 \% \\
0 \% \\
\end{array}$ & $\begin{array}{l}-28 \% \\
-23 \% \\
-21 \% \\
-1 \% \\
\end{array}$ \\
\hline $\begin{array}{r}\text { No primary, primary } \\
\text { Incomplete secondary } \\
\text { Complete secondary } \\
\text { Complete secondary + vocational } \\
\text { Incomplete secondary + vocational } \\
\text { College } \\
\text { Some university } \\
\text { University }\end{array}$ & $\begin{array}{c}-11 \% * \\
-28 \% \\
-30 \% \\
-34 \% \\
-30 \% \\
-29 \% \\
-28 \% \\
-24 \% \\
\end{array}$ & $\begin{array}{l}-6 \% * \\
-19 \% \\
-18 \% \\
-20 \% \\
-18 \% \\
-16 \% \\
-21 \% \\
-15 \% \\
\end{array}$ & $\begin{array}{l}-7 \% \\
-20 \% \\
-21 \% \\
-23 \% \\
-22 \% \\
-17 \% \\
-19 \% \\
-14 \% \\
\end{array}$ \\
\hline \begin{tabular}{r|} 
Managers \\
Professionals \\
Clerks \\
Associate professionals \\
Service workers \\
Craft workers \\
Operators and assemblers \\
Elementary occupations \\
\end{tabular} & $\begin{array}{l}-7 \% * \\
-30 \% \\
-33 \% \\
-19 \% \\
-25 \% \\
-25 \% \\
-22 \% \\
-31 \% \\
\end{array}$ & $\begin{array}{c}8 \% \\
-16 \% \\
-18 \% \\
-13 \% \\
-17 \% \\
-25 \% \\
-18 \% \\
-22 \% \\
\end{array}$ & $\begin{array}{c}7 \% \\
-15 \% \\
-19 \% \\
-14 \% \\
-20 \% \\
-27 \% \\
-20 \% \\
-25 \% \\
\end{array}$ \\
\hline
\end{tabular}

Note: Independent variables in equations are gender, age, age squared, education, occupation, experience, region, settlement type, duration of working week (log) and type of labour contract.

* marks the estimates NON-significant at 5\% level. 
Table 3. Fringe benefits

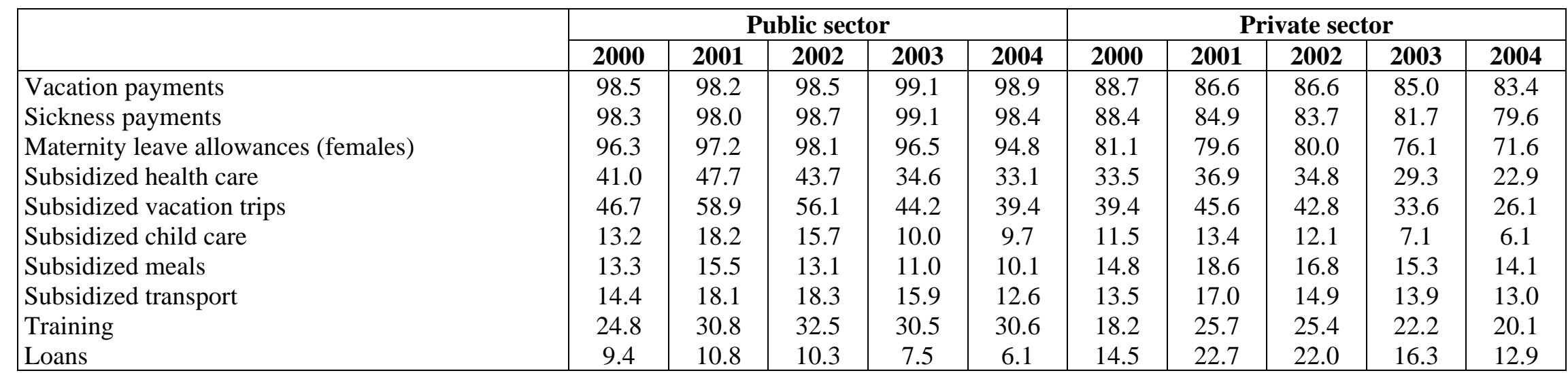


Table 4. Subjective characteristics

\begin{tabular}{|c|c|c|c|c|c|c|c|c|c|c|}
\hline & \multicolumn{5}{|c|}{ Public sector } & \multicolumn{5}{|c|}{ Private sector } \\
\hline & 2000 & 2001 & 2002 & 2003 & 2004 & 2000 & 2001 & 2002 & 2003 & 2004 \\
\hline \multicolumn{11}{|l|}{ Life satisfaction } \\
\hline Satisfied & 19.1 & 24.6 & 34.6 & 33.8 & 38.2 & 19.4 & 24.0 & 34.4 & 34.4 & 40.1 \\
\hline Both yes and no & 24.6 & 23.9 & 26.7 & 26.1 & 26.6 & 24.2 & 25.3 & 27.8 & 26.5 & 26.8 \\
\hline Not satisfied & 56.2 & 51.5 & 38.7 & 40.1 & 35.1 & 56.4 & 50.7 & 37.8 & 39.2 & 33.1 \\
\hline \multicolumn{11}{|l|}{$\begin{array}{l}\text { Are you sure that you will be able to find } \\
\text { a new job? }\end{array}$} \\
\hline & 32.1 & 40.8 & 40.2 & 40.1 & 36.4 & 29.5 & 36.7 & 36.6 & 36.3 & 35.7 \\
\hline Both yes and no & 14.4 & 13.7 & 14.5 & 14.7 & 14.2 & 16.0 & 14.7 & 15.3 & 15.6 & 18.3 \\
\hline No & 53.5 & 45.5 & 45.2 & 45.2 & 49.4 & 54.4 & 48.7 & 48.1 & 48.1 & 46.1 \\
\hline \multicolumn{11}{|l|}{ Are you anxious about job loss? } \\
\hline Yes & 53.7 & 48.4 & 45.9 & 48.2 & 49.9 & 60.4 & 52.5 & 55.0 & 53.5 & 53.9 \\
\hline Both yes and no & 11.7 & 10.1 & 12.4 & 11.8 & 10.2 & 10.6 & 10.8 & 10.2 & 12.4 & 11.6 \\
\hline No & 34.6 & 41.6 & 41.8 & 40.0 & 39.9 & 29.0 & 36.7 & 34.8 & 34.1 & 34.5 \\
\hline Fraction of those who want to change job & 63.8 & 63.9 & 68.2 & 65.9 & 71.5 & 62.1 & 65.5 & 64.1 & 66.0 & 69.6 \\
\hline \multicolumn{11}{|l|}{ Job satisfaction in general } \\
\hline Satisfied & & & 58.0 & 46.8 & 49.2 & & & 49.6 & 43.8 & 44.8 \\
\hline Both yes and no & & & 15.7 & 21.0 & 21.7 & & & 18.1 & 21.6 & 24.6 \\
\hline Not satisfied & & & 26.4 & 32.3 & 29.1 & & & 32.2 & 34.6 & 30.6 \\
\hline \multicolumn{11}{|l|}{ Satisfaction with working conditions } \\
\hline Satisfied & & & 52.0 & 44.4 & 48.2 & & & 44.7 & 41.1 & 41.0 \\
\hline Both yes and no & & & 17.4 & 19.9 & 20.6 & & & 18.8 & 18.5 & 22.0 \\
\hline Not satisfied & & & 30.5 & 35.7 & 31.2 & & & 36.5 & 40.4 & 36.9 \\
\hline \multicolumn{11}{|l|}{ Satisfaction with wage } \\
\hline Satisfied & & & 14.5 & 10.9 & 11.8 & & & 22.3 & 20.9 & 22.0 \\
\hline Both yes and no & & & 11.1 & 9.0 & 10.9 & & & 13.2 & 15.2 & 16.8 \\
\hline Not satisfied & & & 74.4 & 80.1 & 77.3 & & & 64.6 & 64.0 & 61.2 \\
\hline \multicolumn{11}{|l|}{ Satisfaction with career prospects } \\
\hline Satisfied & & & 44.6 & 37.3 & 35.6 & & & 33.6 & 32.1 & 28.6 \\
\hline Both yes and no & & & 15.8 & 17.5 & 21.4 & & & 16.0 & 17.6 & 22.3 \\
\hline Not satisfied & & & 39.6 & 45.3 & 43.0 & & & 50.4 & 50.4 & 49.1 \\
\hline
\end{tabular}


Table 5. Switching regression (RLMS, basic specification)

\begin{tabular}{|c|c|c|c|c|c|c|}
\hline & \multicolumn{4}{|c|}{ Wage equation } & \multirow{2}{*}{\multicolumn{2}{|c|}{ Selection equation }} \\
\hline & \multicolumn{2}{|c|}{ Public sector } & \multicolumn{2}{|c|}{ Private sector } & & \\
\hline & Coeff. & t-stat & Coeff. & t-stat & Coeff. & t-stat \\
\hline Age & 0.056 & 10.91 & 0.033 & 8.61 & -0.017 & -2.10 \\
\hline $\operatorname{Age}^{\wedge 2}$ & -0.001 & -10.31 & 0.000 & -9.73 & 0.000 & 2.16 \\
\hline Gender (female) & 0.388 & 12.92 & 0.326 & 19.74 & -0.304 & -9.18 \\
\hline Marital status (single) & -0.028 & -1.30 & 0.032 & 1.96 & 0.002 & 0.06 \\
\hline \multicolumn{7}{|l|}{ Education (incomplete secondary and less) } \\
\hline Complete secondary & 0.083 & 1.74 & 0.100 & 4.47 & -0.103 & -1.89 \\
\hline College & 0.293 & 6.08 & 0.156 & 6.23 & 0.025 & 0.43 \\
\hline University & 0.517 & 10.22 & 0.418 & 14.50 & 0.020 & 0.32 \\
\hline \multicolumn{7}{|l|}{ Occupation (elementary occupations) } \\
\hline Managers & 0.683 & 10.39 & 0.582 & 15.19 & 0.573 & 7.92 \\
\hline Professionals & 0.653 & 9.19 & 0.387 & 10.16 & 1.180 & 19.88 \\
\hline Associate professionals & 0.544 & 8.62 & 0.395 & 13.13 & 0.756 & 13.25 \\
\hline Служащие & 0.456 & 6.97 & 0.281 & 8.90 & 0.077 & 1.08 \\
\hline Service workers & 0.374 & 6.25 & 0.181 & 5.72 & 0.633 & 9.83 \\
\hline Skilled agricultural workers & 1.179 & 7.50 & 0.064 & 0.63 & -0.523 & -1.85 \\
\hline Craft workers & 0.223 & 1.90 & 0.394 & 15.36 & -0.755 & -8.88 \\
\hline Operators and assemblers & 0.322 & 4.36 & 0.364 & 14.48 & -0.375 & -5.57 \\
\hline Working week $(\ln )$ & 0.445 & 10.50 & 0.388 & 13.61 & -0.556 & -11.27 \\
\hline \multicolumn{7}{|l|}{$\begin{array}{l}\text { Settlement type (rural+urban-type } \\
\text { settlement) }\end{array}$} \\
\hline Moscow and S.-Pb. & 0.333 & 6.68 & 0.864 & 30.30 & -0.513 & -8.89 \\
\hline Regional capital & 0.099 & 3.44 & 0.545 & 26.06 & -0.220 & -5.53 \\
\hline Other towns & 0.187 & 6.33 & 0.613 & 27.29 & -0.209 & -5.06 \\
\hline \multicolumn{7}{|l|}{ Firm size (10 persons and less) } \\
\hline $11-50$ & 0.116 & 2.28 & 0.045 & 1.78 & 0.676 & 13.20 \\
\hline $51-100$ & 0.226 & 3.90 & 0.077 & 2.40 & 0.958 & 16.78 \\
\hline $101-500$ & 0.260 & 5.03 & 0.083 & 3.18 & 0.659 & 12.15 \\
\hline $501-1000$ & 0.223 & 3.30 & 0.148 & 5.09 & 0.303 & 4.20 \\
\hline$>1000$ & 0.218 & 3.33 & 0.223 & 8.18 & -0.161 & -2.16 \\
\hline \multicolumn{7}{|l|}{ Year (2000) } \\
\hline 2001 & 0.149 & 5.23 & 0.189 & 9.02 & -0.008 & -0.20 \\
\hline 2002 & 0.476 & 18.21 & 0.357 & 18.01 & -0.011 & -0.27 \\
\hline 2003 & 0.482 & 18.03 & 0.489 & 24.32 & -0.035 & -0.87 \\
\hline \multicolumn{7}{|l|}{ Region (South) } \\
\hline Centre & 0.088 & 2.62 & 0.246 & 9.48 & -0.177 & -3.65 \\
\hline North-West & 0.375 & 9.54 & 0.480 & 16.08 & 0.011 & 0.19 \\
\hline Volga & 0.002 & 0.06 & -0.053 & -2.16 & 0.036 & 0.73 \\
\hline Urals & 0.341 & 7.29 & 0.289 & 8.63 & -0.084 & -1.34 \\
\hline Siberia & 0.151 & 4.52 & 0.017 & 0.62 & -0.084 & -1.58 \\
\hline Far East & 0.382 & 8.61 & 0.274 & 7.81 & -0.097 & -1.38 \\
\hline Children under 7 in the household & & & & & 0.117 & 3.44 \\
\hline Constant & 2.606 & 16.68 & 3.775 & 28.43 & 1.082 & 4.61 \\
\hline
\end{tabular}

